\title{
Note
}

\section{Escherichia coli K88 adhesion : A comparison of Chinese and Large White piglets}

\author{
J.P. CHAPPUIS *, Yvonne DUVAL-IFLAH *, L. OLLIVIER ** and C. LEGAULT ** \\ * I.N.R.A., Laboratoire d'Ecologie microbienne \\ ** Station de Génétique quantitative et appliquée, Centre de Recherches zootechniques,
}

F 78350 Jouy-en-Josas

\begin{abstract}
Summary
A comparative trial was performed on 15 Large White and 12 Chinese germ-free, colostrumdeprived piglets, maintained in plastic film isolators. Shortly after successive oral inoculations of $2 E$. coli strains, one K88-positive and one K88-negative, the piglets were sacrificed and bacterial numerations of the 2 strains were done on 3 different intestinal segments of each pig, using both the lumen content and the washed intestinal wall. The percentage of bacteria specifically bound to the intestinal wall was estimated, and the presence or absence of the piglet K88 intestinal receptor was thus inferred. The results tended to indicate that the 12 Chinese piglets lacked this receptor, as against 7 Large White's. This raises the question of possible breed differences in resistance to this type of colibacillosis.
\end{abstract}

Key words : K88 adhesion, E. coli, pig, genetic resistance.

\author{
Résumé \\ L'attachement de Escherichia coli K88 : \\ comparaison entre porcelets Chinois et Large White
}

Un essai comparatif a été réalisé sur 15 porcelets Large White et 12 porcelets Chinois, prélevés à la naissance de manière axénique, privés de colostrum et placés en isolateur sous film plastique. Après inoculation par voie orale de 2 souches de $E$. coli, l'une possédant l'antigène d'attachement $\mathrm{K} 88\left({\mathrm{~K} 88^{+}}^{+}\right)$, l'autre dépourvue de cet antigène $\left(\mathrm{K}^{-} 8^{-}\right)$, les porcelets sont sacrifiés et 3 segments différents de l'intestin grêle sont prélevés sur chaque porcelet en vue de numérations des 2 souches bactériennes, à la fois dans le contenu intestinal et sur la paroi. Le pourcentage de bactéries spécifiquement attachées à la paroi est ainsi estimé et la présence ou l'absence chez le porcelet du récepteur intestinal K88 peut en être déduite. Les résultats indiquent que les 12 porcelets Chinois ne possèdent pas ce récepteur et doivent donc être résistants à l'attachement de K88, contre 7 porcelets Large White. Cela soulève la question de l'existence possible de races résistantes à cette colibacillose.

Mots clés : Attachement de K88, E. coli, porcs, résistance génétique. 
It is recognized that most porcine neonatal diarrhoea are due to proliferation of enterotoxigenic $E$. coli strains in the small intestine (reviewed by SoJKA, 1971). From 34 to 56 p. 100 of the $E$. coli strains isolated from diarrhoeal piglets by GUINEE \& JANSEN (1979), SODERLIND \& MÓlLBY (1979) and MOON et al. (1980) possessed a surface antigen called $\mathrm{K} 88$, which enables bacteria to adhere to receptor sites located on the intestinal epithelium (ARBUCKLE, 1970 ; JONES \& RUTTER, 1972 ; BERTSCHINGER et al., 1972 ; WiLSON \& HoHMANN, 1974). Three serological variants of this K88 antigen (i.e. K88ab, K88ac and K88ad) have been described by ØRSKOV et al. (1964) and GUINEE \& JANSEN (1979).

The discovery of a genetic basis for resistance to K88 adhesion has aroused a considerable interest (SELlwOod et al., 1974). Genetically resistant piglets lack the intestinal receptor and the genetic basis is monofactorial, a recessive gene conferring resistance. The system has been described in detail by GibBons et al. (1977), who also offered an explanation for the persistence of the susceptibility gene in pig populations. They assumed that the heterozygous genotype might be at a disadvantage, owing to the inability of a resistant sow to produce K88 antibodies. By observing the incidence of an outbreak of diarrhoea in an experimental herd with various combinations of piglet and sow genotypes, SELlwOOD (1979) was able to afford some experimental support to the above hypothesis and, in particular, he showed that the highest incidence of diarrhoea was in the susceptible progeny of resistant dams. Recently, the existence of several adhesive pig phenotypes has been suggested by BIJLSMA et al. (1981), in connection with the antigenic variation of K88. In fact, these authors show the existence of a non-adhesive phenotype, resistant to the 3 serological variants, and of 4 different pig phenotypes exhibiting adhesion to at least one K88 variant. The genetic basis of this variation appears to be still unresolved.

This genetic resistance exists at variable frequencies in the pig populations so far investigated : from 9 to 90 p. 100 homozygous resistant pigs in U.K. herds (WALTERS \& SEllwood, 1982), 60 p. 100 in a Swedish Yorkshire $\times$ Landrace stock (EDFORS-LILJA et al., 1982), 12 p. 100 in a commercial herd in Australia (SNODGRAss et al., 1981). But in those studies resistance was assessed by applying the in vitro brush border test of SELLwOOD et al. (1975), with no specification of the K88 variant used in the tests, though the K88ac variant was used in the original paper just mentioned. The differences observed may thus result from variations of the $E$. coli tester strains. However no breed differences appear to have been so far suggested. This note reports observations indicating that such differences could exist and that even the existence of homozygous resistant breeds is not to be excluded.

Our results were obtained while investigating interactions between several Escherichia coli strains in the digestive tract of germ-free, colostrum deprived piglets maintained in plastic film isolators and fed with autoclaved concentrated cow milk. These animals were orally inoculated with $10^{9}$ viable cells of different $E$. coli strains cultivated at $37^{\circ} \mathrm{C}$ for $18 \mathrm{~h}$. It was first shown that 2 day-old Large White piglets inoculated with an enterotoxigenic $E$. coli strain possessing the $\mathrm{K} 88$ antigen (strain $\mathrm{K}^{+} 8^{+} \mathrm{Ent}^{+}$) usually die within 2 days (Duval-IFlaH et al., 1983). However, when the same treatment was applied to a couple of Chinese piglets born from the Chinese stock imported in France in 1979 and described by LEGAULT \& CARITEZ (1983), these animals survived up to 6 days. The same survival time was obtained when 2 day-old germ-free Large White piglets were inoculated with an enterotoxigenic $E$. coli strain lacking the K88 antigen $\left(\mathrm{Ent}^{+} \mathrm{K}^{-} 8^{-}\right.$). These preliminary results suggested that Chinese piglets might be resistant to attachment of the $\mathrm{K} 88 \mathrm{E}$. coli strain. This prompted us to realize a comparative trial 
on germ-free, colostrum deprived piglets maintained in the same conditions as those mentioned above in order to test for K88 adhesion. Twelve Chinese piglets, 6 from the Meishan breed and 6 from the Jiaxing breed, as well as 15 Large White (LW) piglets were used. When they were 2 day-old, they were orally inoculated with $10^{9}$ viable cells from an $18 \mathrm{~h}$ culture of a non enterotoxigenic $E$. coli strain lacking the K88 antigen

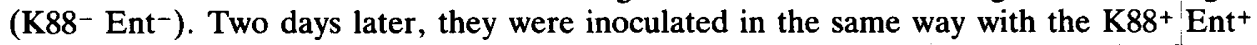
strain. The animals were sacrificed $18 \mathrm{~h}$ later and treated as described by SMITH \& LiNGGOOD (1971), except for the fact that only 3 segments were removed from the small intestine : 1 from the proximal end of jejunum (S1), 1 from the jejuno-ileal junction (S2) and 1 from the distal end of ileum (S3). Bacterial numerations of the 2 associated strains were performed in the lumen content and on the washed intestinal wall using selective media as previously described (DUVAL-IfLAH et al., 1982).

A number of non specifically attached bacteria (NA) is retained on the intestinal wall, due to lumen residues which cannot be fully washed off. Therefore, the ratio of attached (A) to non-attached (NA) bacteria is used as an in vivo adhesion test. However, A/NA cannot be directly measured, but it is estimated in the following manner, knowing the ratios of the 2 strains counted in the washed intestinal wall $(P)$ and in the lumen content (p) respectively. Under the assumption that lumen residues remaining on the

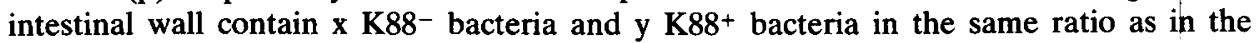

TABLE 1

Discrimination between adherent and non-adherent intestines.

Différenciation des intestins adhérents et non-adhérents.

\begin{tabular}{|c|c|c|c|}
\hline $\begin{array}{l}\text { Breed } \\
\text { (race) }\end{array}$ & $\begin{array}{l}\text { Strains } \\
\text { (souches) }\end{array}$ & $\begin{array}{c}\text { Range (a) of the A/NA ratio } \\
\text { (étendue de variation } \\
\text { du rapport } A / N A)\end{array}$ & $\begin{array}{l}\text { Adherence } \\
\text { (adhésion) }\end{array}$ \\
\hline $\begin{array}{l}\text { Large } \\
\text { White }\end{array}$ & $\begin{array}{l}\mathrm{K} 88^{-} \text {Ent }^{+} \\
\text {and } \\
\mathrm{K}^{-} 8^{-} \text {Ent }^{-}\end{array}$ & $8^{\text {(b) }}$ & - \\
\hline $\begin{array}{l}\text { Large } \\
\text { White }\end{array}$ & 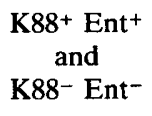 & 7 (b) & $\begin{array}{l}- \\
+\end{array}$ \\
\hline \multirow[t]{2}{*}{ Chinese } & $\begin{array}{l}\mathrm{K} 88^{+} \mathrm{Ent}^{+} \\
\text {and } \\
\mathrm{K}^{-} 8^{-} \text {Ent }^{-}\end{array}$ & 12 (b) & - \\
\hline & $\begin{array}{c}\text { Scale } \\
\text { (échelle) }\end{array}$ & $\begin{array}{lll} & 1 & \\
0 & 8 & 200\end{array}$ & \\
\hline
\end{tabular}

(a) The range given represents the extreme limits of the 95 p. 100 confidence intervals for A/NA in the segment with the highest $A / N A$ value in each piglet.

(L'étendue indiquée représente les limites extrêmes de l'intervalle de confiance à 95 p. 100 pour A/NA dans le segment avec la valeur $A / N A$ la plus élevée de chaque porcelet.)

(b) Number of piglets. (Nombre de porcelets). 
lumen content, the $\mathrm{P}$ ratio exceeds $\mathrm{p}$ by a quantity which only depends on the number $A$ of $\mathrm{K} 88^{+}$bacteria attached to the intestinal wall, and thus $P=(x+A) / y$, whereas $\mathrm{p}=\mathrm{x} / \mathrm{y}$. As the total number of non-attached bacteria, $\mathrm{K}^{+} 8^{+}$and $\mathrm{K}^{-} 8^{-}$, is $\mathrm{NA}=\mathrm{x}+\mathrm{y}$, it can easily be seen that $\mathrm{A} / \mathrm{NA}=(\mathrm{P}-\mathrm{p}) /(\mathrm{p}+1)$.

$P$ and $p$ can be directly evaluated from bacterial counts performed on intestinal wall and in lumen content, respectively. However, the A/NA ratio is subject to rather large sampling variation. Therefore, 8 Large White piglets have been inoculated as described above, except for the fact that they received the $\mathrm{K}^{-} 8^{-} \mathrm{Ent}^{+}$strain instead of the $\mathrm{K} 88^{+} \mathrm{Ent}^{+}$one, in order to evaluate the maximal values which may be reached by this ratio in the absence of bacterial attachment. Table 1 shows that the upper limit of the 95 p. 100 confidence interval of the A/NA ratio obtained with these Large White piglets never exceeds 8 . Similar results were obtained with 12 Chinese piglets inoculated

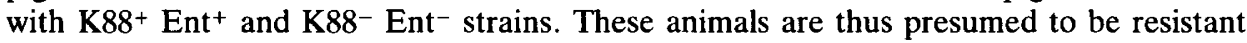
to $\mathrm{K} 88$ attachment. On the contrary, in 8 Large White piglets associated with $\mathrm{K}^{8} 8^{+} \mathrm{Ent}^{+}$

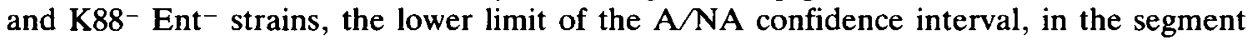
with the highest A/NA value in each piglet, always exceeds 8 , which indicates that they are susceptible to $\mathrm{K} 88$ attachment. Table 2 gives the mean bacterial population levels found on the intestinal walls of piglets which have just been described and the mean $\mathrm{A} / \mathrm{NA}$ in all segments.

\section{TABLE 2}

Viable counts of Escherichia coli on intestinal tissues of gnotobiotic piglets.

Numérations de Escherichia coli dans les tissus intestinaux de porcelets gnotobiotiques.

\begin{tabular}{|c|c|c|c|c|c|c|c|}
\hline \multirow{2}{*}{$\begin{array}{l}\text { Breed } \\
\text { (Race) }\end{array}$} & \multirow{2}{*}{$\begin{array}{l}\mathrm{Nb} \text { piglets } \\
\text { (Nombre de } \\
\text { porcelets) }\end{array}$} & \multirow{2}{*}{$\begin{array}{c}\text { Strains } \\
\text { (Souches) }\end{array}$} & \multicolumn{3}{|c|}{$\begin{array}{l}\text { Mean (s.d.) of } \log _{10} \text { E. coli (a) } \\
{\left[\text { Moyenne (e.t.) de } \log _{10} \text { E. coli] }\right.}\end{array}$} & \multirow{2}{*}{$\begin{array}{c}\text { Mean of } \\
\text { A/NA ratio } \\
\text { (Moyenne } d u \\
\text { rapport } A / N A)\end{array}$} & \multirow{2}{*}{$\begin{array}{c}\text { Presumed (b) } \\
\text { phenotype } \\
\text { (Phénotype } \\
\text { présumé) }\end{array}$} \\
\hline & & & S1 & $\$ 2$ & S3 & & \\
\hline $\begin{array}{l}\text { Large } \\
\text { White }\end{array}$ & 8 & $\begin{array}{l}\text { K88- Ent } \\
\text { K88- Ent }\end{array}$ & $\begin{array}{l}6.9(0.7) \\
6.7(0.4)\end{array}$ & $\begin{array}{l}6.6(1.5) \\
6.3(1.0)\end{array}$ & $\begin{array}{l}7.3(0.2) \\
6.9(0.2)\end{array}$ & 1.03 & $\begin{array}{l}\text { Control } \\
\text { piglets }\end{array}$ \\
\hline $\begin{array}{l}\text { Large } \\
\text { White }\end{array}$ & 8 & $\begin{array}{l}\text { K88+ Ent } \\
\text { K88- Ent }\end{array}$ & $\begin{array}{l}7.8(1.1) \\
5.2(2.3)\end{array}$ & $\begin{array}{l}8.5(0.6) \\
6.4(1.1)\end{array}$ & $\begin{array}{l}8.5(0.6) \\
6.2(0.9)\end{array}$ & 29.4 & Adherent \\
\hline $\begin{array}{l}\text { Large } \\
\text { White }\end{array}$ & 7 & $\begin{array}{l}\mathrm{K}^{8} 8^{+} \text {Ent }^{+} \\
\text {K88- Ent }\end{array}$ & $\begin{array}{l}5.4(1.9) \\
5.2(1.3)\end{array}$ & $\begin{array}{l}6.6(1.2) \\
6.8(0.8)\end{array}$ & $\begin{array}{l}6.7(1.5) \\
6.9(1.3)\end{array}$ & 0.51 & $\begin{array}{c}\text { Non } \\
\text { adherent }\end{array}$ \\
\hline Chinese & 12 & $\begin{array}{l}\text { K88+ Ent } \\
\text { K88- Ent }\end{array}$ & $\begin{array}{l}4.9(1.3) \\
5.5(1.9)\end{array}$ & $\begin{array}{l}4.6(1.3) \\
5.7(0.9)\end{array}$ & $\begin{array}{l}5.5(0.9) \\
6.6(0.7)\end{array}$ & 0.44 & $\begin{array}{c}\text { Non } \\
\text { adherent }\end{array}$ \\
\hline
\end{tabular}

(a) Mean number of $E$. coli per $g$ of tissue, expressed in $\log _{10}$ and standard deviation in brackets ; S1, S2 and S3 are intestinal segments removed from the jejunal proximal end, the jejuno-ileal junction and the ileal distal end, respectively.

(Nombre moyen de $\mathrm{E}$. coli par $g$ de tissu, exprimé en $\log _{10}$ et écart-type entre parenthèses; $S 1, S 2$ et $S 3$ sont les segments prélevés respectivement à l'extrémité proximale du jéjunum, à la jonction jéjuno-iléale et à l'extrémité distale de l'iléon.)

(b) Classification explained in table 1. (Voir le tableau 1 pour la classification.) 
The $E$. coli strain used in this experiment bears the $\mathrm{K} 88 \mathrm{ab}$ antigen and, from the previously mentioned results of BIJLSMA et al. (1981), the " resistant piglets" of our sample may be resistant, either to the 3 variants or to only 2 of them. Further tests are therefore needed before definite conclusions can be reached. In view of this, it would certainly be unsafe to draw firm conclusions as to the status of the 2 Chinese breeds investigated with respect to $\mathrm{K} 88$ adhesion. Further reasons to be cautious are the limited sample size and the restricted sampling within breed (only 3 sires and 9 dams in the Large White sample and 2 sires and 3 dams in the Chinese sample, this one resulting from an initial importation of only 1 male and 2 females of each breed). Our results only suggest the possibility of genetic variation between breeds for that character. However, if the above results happened to be confirmed, the implications of breed resistance to $\mathrm{K} 88$ diarrhoea would deserve consideration. The question could also be raised of a possible link between such a resistance and the low preweaning mortality generally observed in Chinese breeds and confirmed by the 3 p. 100 mortality (relative to born alive) observed in purebred litters of the 2 above-mentioned breeds by LEGAULT \& CARITEZ (1983). This could be an example of a favourable gene preserved under certain farm conditions and for which selection would appear to be " relaxed" in modern pig husbandry conditions.

Received November 28, 1983.

Accorded March 13, 1984.

\section{References}

ArbuCKLE J.B.R., 1970. The location of Escherichia coli in the pig intestine. J. Med. Microbiol., 3, 333-340.

Bertschinger H.U., Moon H.W., Whipp S.C., 1972. Association of Escherichia coli with the small intestinal epithelium. I. Comparison of enteropathogenic and nonenteropathogenic porcine strains in pigs. Infect. Immun., 5, 595-605.

BiJlSMa I.G.W., DenIJS A., FrIK J.F., 1981. Adherence of Escherichia coli to porcine intestinal brush borders by means of serological variants of the K88 antigen. Antonie van Leeuwenhoek J. Microbiol. Serol., 47, 467-468.

Duval-Iflah Y., Chappuis J.P., Ducluzeau R., Raibaud P., 1983. Intraspecific interactions between Escherichia coli strains in human newborns and in gnotobiotic mice and piglets. Prog. Fd. Nutr. Sci., 7, 107-116.

Edfors-Lilja I., Petersson H., Gahne B., 1982. The intestinal receptor for E. coli K88 in relation to performance of sw. Yorkshire $\times$ sw. Landrace pigs. In : 2nd World Congress on Genetics applied to Livestock Production, vol. VII, 390-394, Editorial Garsi, Madrid.

Gibbons R.A., Sellwood R., Burrows M., Hunter P.A., 1977. Inheritance of resistance to neonatal E. coli diarrhoea in the pig : examination of the genetic system. Theor. Appl. Genet., $51,65-70$.

GUINEE P.A.M., JANSEN W.H., 1979. Behavior of Escherichia coli K antigens K88ab, K88ac and K88ad in immunoelectrophoresis, double diffusion and hemagglutination. Infect. Immun., 23, 700-705.

JONES G.W., RUTTER J.M., 1972. Role of the K88 antigen in the pathogenesis of neonatal diarrhea caused by Escherichia coli in piglets. Infect. Immun., 6, 918-927.

Legault C., Caritez J.C., 1983. L'expérimentation sur le porc chinois en France. I. Performances de reproduction en race pure et en croisement. Génét. Sél. Evol., 15, 225-240.

Moon H.W., Kohler E.M., SChneider R.A., Whipp S.C., 1980. Prevalence of pilus antigens, enterotoxin types and enteropathogenicity among K88-negative enterotoxigenic Escherichia coli from neonatal pigs. Infect. Immun., 27, 222-230. 


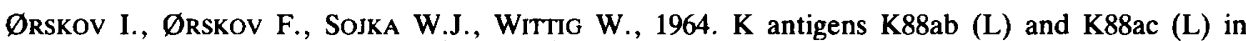
E. coli. A new O antigen : 0147 and a new K antigen : K89 (B). Acta Pathol. Microbiol. Scand. Sect. B, 62, 439-447.

SEllwood R., 1979. Escherichia coli diarrhoea in pigs with or without the K88 receptor. Vet. Rec., 105, 228-230.

Sellwood R., Gibbons R.A., Jones G.W., RutTer J.M., 1974. A possible basis for the breeding of pigs relatively resistant to neonatal diarrhoea. Vet. Rec., 95, 574-579.

Sellwood R., Gibbons R.A., Jones G.W., RutTer J.M., 1975. Adhesion of enteropathogenic Escherichia coli to pig intestinal brush borders : the existence of two pig phenotypes. J. Med. Microbiol., 8, 405-411.

SMITH H.W., LINGGOOD M.A., 1971. Observations on the pathogenic properties of the K88, Hly and Ent plasmids of E. coli with particular reference to porcine diarrhoea. J. Med. Microbiol., 4, 467-485.

SNOdgrass D.R., Chandler D.A., MAKIN T.J., 1981. Inheritance of Escherichia coli K88 adhesion in pigs : identification of nonadhesive phenotypes in a commercial herd. Vet. Rec., 109, 461-463.

SÓDERLIND O., MÖlby R., 1979. Enterotoxins, O-groups and K88 antigen in Escherichia coli from neonatal pigs with and without diarrhoea. Infect. Immun., 24, 611-616.

SOJKA W.J., 1971. Enteric diseases in newborn piglets, calves and lambs due to Escherichia coli infection. Vet. Bull., 41, 509-522.

Walters J.R., Sellwood R., 1982. Aspects of genetic resistance to K88 E. coli in pigs. In : 2nd World Congress on Genetics applied to Livestock Production, vol. VII, 362-367, Editorial Garsi, Madrid.

Wilson M.R., HohmanN A., 1974. Immunity to Escherichia coli in pigs : adhesion of enteropathogenic Escherichia coli to isolated intestinal epithelial cells. Infect. Immun., 10, 776-782. 